\title{
Effect of the addition of pearl millet flour subjected to different processing on the antioxidants, nutritional, pasting characteristics and cookies quality of rice-based composite flour
}

\begin{abstract}
Composite flour was developed from rice, soybean, tigernut and millet composite flours; with the millet subjected to different processing techniques such as debranning, fermentation and malting in other to determine the effect of processing methods on the quality of the flour. The proximate composition, functional properties and pasting characteristics, of the composite flour were evaluated. Cookies were produced from the best blend from each of the malted, fermented and debranned millet composite flours. The results showed that flour blend with malted millet had the highest ash and fiber contents. Composite flour consisting fermented millet had the highest protein content, functional properties and pasting characteristics. In terms of pasting properties, composite flour with fermented millet was the best followed by flour blend with malted millet. Cookies produced from the flour blend with fermented millet had the highest overall acceptability. The result showed that the quality of flour and biscuits were improved by the processing techniques and that the composite flour were good raw materials that could produce quality composite flour and acceptable cookies.
\end{abstract}

Keywords: debranning, cookies, composite flour, fermentation, pasting, proximate, malting
Volume 7 Issue 2 - 2017

\author{
Olugbenga Olufemi Awolu, Olayinka Ayo \\ Olarewaju, Adenike Oluwatosin Akinade \\ Department of Food Science and Technology, Federal University \\ of Technology, Nigeria
}

Correspondence: Olugbenga Olufemi Awolu, Department of Food Science and Technology, Federal University of Technology, Akure, Nigeria, Email ooawolu@futa.edu.ng

Received: October 04, 2017 | Published: October 20, 2017

\section{Introduction}

Biscuit is a popular bakery product worldwide. Biscuit is widely accepted by all age group due to its longer shelf life, better taste and its position as snacks; it is also considered as a good product for protein fortification and other nutritional improvement. ${ }^{1}$ Due to competition in the market and increase demand for healthy, natural, and functional products, attempt are been made to improve the nutritive value of cookies and functionality by modifying their nutritive. ${ }^{2}$ Composite flour are being developed consisting as a substitute to primarily wheat flour in the production of baked products. ${ }^{3,4}$ Composite flours consisting cereals with legumes, fibre sources and hydrocolloids which can serve as viable alternatives to wheat flour have been researched into..$^{5-9}$ Major advantages of these composite flours are their enhanced nutritional (protein, antioxidants, fibre, minerals) in addition to being gluten-free. ${ }^{6,7}$ In addition, composite flours enhance the utilization of local and underutilized local and inexpensive food raw materials in the production of bakery products. Millets (Penisetum glaucum) are groups of small seeded species of cereal crops or grains, widely grown around the world for food and staples. ${ }^{10}$ Millet could also be malted and milled into flour or brewed into various drinks and can be as well dehulled and milled into flour. Millet is predominantly starchy and the bran layer of millet is good sources of b-complex vitamins. ${ }^{11}$ It also serves as a source of antioxidant in our diets. ${ }^{11}$

Rice (Oritza sativa) is a principal leading food crop of the world and a staple food of over approximately half of the world's population. Rice flour is considerably lower in protein content compared with wheat flour and does not contain gluten, hence, it is good source of flour for people who are gluten intolerant. ${ }^{12}$ Extruded snack with high nutritional and antioxidant properties have been developed from ricebased composite flour. ${ }^{3}$

Soybean (Glycine max) is a remarkable source of protein for both animals and human consumption and is also a leading source of edible oils and fats. ${ }^{13}$ Soybean is the only source that contains all the amino acids, it is used in the production of bread, cookies and other composite flour has been reported. ${ }^{14-16}$ Soybean is cheap and this with its advantage of high nutrient makes it widely accepted and used for various forms of meals and snacks.

Tiger nut (Cyperusesculentus) is an underutilized crop reported to be high in dietary fibre content which could be effective in the treatment and prevention of many disease including colon cancer, coronary heart diseases, heart diseases, obesity and gastro intestinal disorder. ${ }^{17}$ Tiger nut flour has been demonstrated to be a rich source of quality oil, vitamin $\mathrm{E}$ and contains some useful minerals such as iron and calcium which are essential for body growth and development. ${ }^{18}$ Due to its high amino acids contents, tiger nut has inherent nutritional and therapeutic advantage which could serve as a good alternative to cassava in baking industry.

This study therefore focus on making a quality and functional cookies from composite flour comprising of millet, rice, soybean, and tiger nut, using carboxyl methyl cellulose as a binder. The millet was subjected various processing techniques (debranning, fermentation and malting) in order to ascertain the effect of the processing techniques on the nutritional and dough properties. 


\section{Materials and methods}

\section{Materials}

The millet, rice, soybean seed and tiger nut seed were purchased from Oba market, Akure, Ondo state Nigeria.

\section{Methods}

Pearl millet debranning: The pearl millet grains were cleaned to removed dirt, sand and other extraneous material by winnowing. The cleaned grain were then soaked in water for $18 \mathrm{~h}$ to soften the seed coat and to allow easy removal of the bran containing phytic compounds. The debranning was manually carried out and the debranned grain oven-dried until constant moisture content was obtained. It was later milled in an attrition mill, sieved and the pearl millet flour obtained stored in sealed polythene bags at room temperature for analysis.

Pearl millet fermentation: The pearl millet was fermented using the method of Lei and Jacobsen. ${ }^{19}$ The pearl millet was sorted to remove extraneous material, thoroughly washed in clean water, soaked soaked in water for $48 \mathrm{~h}$ to ferment, the fermented millet was oven-dried to constant moisture, milled and sieved and stored in sealed polythene bag for further processing.

Pearl millet malting: The malting of the pearl millet was carried out using the method of. ${ }^{20}$ The malting process comprises of three main stages: steeping, germination and drying. Pearl millet was sorted and washed five times to remove foreign materials. The grains was put in a large nylon bag and was spin dried to remove excess surface held water, it was then tied at the mouth, the grain in the nylon bags was steeped in static water at room temperature, with a cycle of $2 \mathrm{~h}$ wet and $2 \mathrm{~h}$ dry air-rest, for $8 \mathrm{~h}$. During the air-rests, the grain was held in still air at $20-22^{\circ} \mathrm{C}$. After steeping, the grain was spin-dried (30s at $30 \mathrm{xg}$ ) and reweighed. The grain was then left in the nylon bag for germination for five days at room temperature. The germinated grain was oven-dried, milled and sieved and stored in sealed polythene bag for further processing.

Preparation of rice flour: Rice flour was prepared using the method adopted by Awolu $\mathrm{OO}$ et al., ${ }^{3}$ The rice grains $(5 \mathrm{Kg})$ were sorted, washed, oven-dried and milled into flour.

Preparation of tiger nut flour: The method of Adeyemi ${ }^{21}$ was used. Dry tigernuts were sorted to remove unwanted materials, thoroughly washed, oven-dried at $60^{\circ} \mathrm{C}$ for $24 \mathrm{~h}$. The dried nuts were milled and sieved to obtain very fine flour; the resultant flour was packed and sealed in polythene bags for further analyses.

Blends preparation: Fifteen blends were prepared by mixing rimillet, soy and tigernut flours with $0.2 \mathrm{~g}$ carboxyl methyl cellulose (CMC) binder (Table 1). Samples were labelled A, B and C for composite flours comprising malted, fermented and debranned millet flours respectively.

Table I Blend formulation for the composite flour

\begin{tabular}{llllll}
\hline *Samples & Rice flour & Malted millet flour & Soybean flour & Tigernut flour & C.M.C \\
\hline A1 & 100 & 0 & 5 & 5 & 0.2 \\
A2 & 90 & 10 & 5 & 5 & 0.2 \\
A3 & 80 & 20 & 5 & 5 & 0.2 \\
A4 & 70 & 30 & 5 & 5 & 0.2 \\
A5 & 60 & 40 & 5 & 5 & 0.2 \\
Fermented & millet flour & & & & \\
B1 & 100 & 0 & 5 & 5 & 0.2 \\
B2 & 90 & 10 & 5 & 5 & 0.2 \\
B3 & 80 & 20 & 5 & 5 & 0.2 \\
B4 & 70 & 30 & 5 & 5 & 0.2 \\
B5 & 60 & 40 & 5 & 5 & 0.2 \\
De-Branned millet flour & & & 5 & \\
C1 & 100 & 0 & 5 & 5 & 0.2 \\
C2 & 90 & 10 & 5 & 5 & 0.2 \\
C3 & 80 & 20 & 5 & 5 & 0.2 \\
C4 & 70 & 30 & 5 & 5 & 0.2 \\
C5 & 60 & 40 & 5 & 5 & 0.2 \\
\hline
\end{tabular}

*AI, BI, CI = 100:0:5:5:0.2 (rice: millet: soy: tigernut: $\mathrm{CMC}$ )

*A2, B2, C2 = 90:10:5:5:0.2 (rice: millet: soy: tigernut: CMC)

$* A 3, B 3, C 3=80: 20: 5: 5: 0.2$ (rice: millet: soy: tigernut: CMC)

*A4, B4, C4 = 70:30:5:5:0.2 (rice: millet: soy: tigernut: CMC)

$* A 5, B 5, C 5=60: 40: 5: 5: 0.2$ (rice: millet: soy: tigernut: $C M C$ )

Citation: Awolu OO, Olarewaju OA, Akinade A. Effect of the addition of pearl millet flour subjected to different processing on the antioxidants, nutritional, pasting characteristics and cookies quality of rice-based composite flour.J Nutr Health Food Eng. 2017;7(2):247-256. DOI: 10.15406/jnhfe.2017.07.00232 
Biscuit production: Biscuits were produced from the blend formulations using the two stage creaming-up method. The baking formula is as described by Ihekoronye A. ${ }^{22}$ All ingredients except flour and sodium bicarbonate were added with continued mixing. The dough was then placed on a cutting board, rolled out until uniform thickness and textures were obtained. Biscuit cutter was used to cut the sheet of rolled dough into desired shapes and sizes. The shaped dough pieces were then baked at about $220^{\circ} \mathrm{C}$ for $15 \mathrm{~min}$, allowed to cool, packed and stored. ${ }^{14}$ The flow chart in Figure 3.6 shows the procedure for biscuit production.

Sensory evaluation: The method used by Awolu et al., ${ }^{6}$ was adopted. Sensory evaluations of the biscuit samples were evaluated for taste, appearance, aroma, texture, and overall acceptability by a panel of ten members using a 9-point Hedonic scale. The rating of the samples ranged from 1 (Dislike extremely) to 9 (Like extremely) conducted by 10 panelists.

Determination of proximate composition of the composite flour: Moisture, total ash, crude fat (Solvent extraction) and crude fibre contents of the composite flours were determined using the standard methods of Association of Official Analytical Chemists. ${ }^{23}$ The crude protein content was determined by the micro Kjeldahl nitrogen method and the nitrogen content was converted to protein using a 6.25 conversion factor. Carbohydrate content was determined by difference.

Determination of water and oil absorption capacity of the composite flour: The water and oil absorption capacity of the composite flours were determined as described by Fagbemi et al. ${ }^{24}$ adapted from Sathe et al. ${ }^{25}$ For water absorption capacity, $10 \mathrm{ml}$ of water was added to $1.0 \mathrm{~g}$ of the flour sample in a beaker and stirred using magnetic stirrer for $5 \mathrm{~min}$. The resulting suspension was centrifuged for $30 \mathrm{~min}$ at $2,500 \times \mathrm{g}$. The supernatant was decanted and the volume measured. The volume of water and oil absorbed was calculated as the difference between the initial volume of water/oil used and the final volume of the decanted supernatant. The result was expressed in percentage

Determination of bulk density and least gelation capacity: The bulk density was determined as described by Fagbemi et al., ${ }^{24}$ some quantity of the flour sample was transferred to a pre-weighed measuring cylinder (W1) and the new weight (W2) was recorded. The volume occupied by the flour in the measuring cylinder was recorded. The bulk density was expressed by the Equation (1)

$$
\text { BulkDensityg } / m l=\frac{W 2-W 1}{\text { Volumeofsample }}
$$

The least gelation concentration (LGC) was determined using the procedure of Coffman and Garcia. ${ }^{26}$ Flour sample suspensions of $2-20 \%(\mathrm{w} / \mathrm{v})$ were prepared in distilled water. An aliquot of $10 \mathrm{ml}$ from each sample suspension was transferred to different test tubes which were heated in a gentle boiling water bath for $60 \mathrm{~min}$. The test tubes were then cooled rapidly in a water bath for $2 \mathrm{~h}$, followed by further cooling in $4^{\circ} \mathrm{C}$ water bath. The LGC was taken as the concentration when the samples in the test tubes did not fall or slip when inverted.

Determination of swelling power and solubility index: Swelling power and solubility index were determined using the procedure of Takashi and Sieb. ${ }^{27}$ Briefly Sample $(1 \mathrm{~g})$ was weighed into $50 \mathrm{ml}$ centrifuge tube and $50 \mathrm{ml}$ of distilled water was added and mixed gently. The slurry was heated in a water bath at $50,60,75,90^{\circ} \mathrm{C}$, respectively for $15 \mathrm{~min}$. During heating, the slurry was stirred gently to prevent clumping of the starch. After $15 \mathrm{~min}$, the tubes containing the paste were centrifuged at $3000 \mathrm{xg}$ for $10 \mathrm{~min}$ using SPECTRA U.K. (Merlin 503) centrifuge. The supernatant was decanted immediately and the weight of the sediment was taken and recorded. The moisture content of the gel was thereafter determined to get the dry matter content of the gel. Swelling power was determined using Eq. (2)

$$
\text { SwellingPower }(\mathrm{g} / \mathrm{g})=\frac{\text { Weightofmasssediment }}{\text { Weightofdrymatteringel }}
$$

Determination of dispensability: Dispensability was determined by the method described by Kulkarni et al. ${ }^{28}$ The flour $(10 \mathrm{~g})$ was suspended in $100 \mathrm{ml}$ measuring cylinder and distilled water was added to reach a volume of $100 \mathrm{ml}$. The set up was stirred vigorously and allowed to settle for $3 \mathrm{~h}$. The volume of settled particles was recorded and subtracted from 100. The difference was reported as percentage dispersibility.

Determination of pasting properties: Pasting properties of flour was characterized using Rapid Visco Analyser (RVA) Model 3C, Newport Scientific PTY Ltd., Sydney as described by Sanni et al. ${ }^{29}$

Determination of minerals: The method described by AOAC (2000) was used. About $2 \mathrm{~g}$ of the sample was placed in the crucibles, ashed in a muffle furnace at $550^{\circ} \mathrm{C}$ for $5 \mathrm{~h}$ and then transferred into the desiccators to cool. The ashed sample was digested with $3 \mathrm{~cm}^{3}$ of $3 \mathrm{M}$ $\mathrm{HCl}$ and made up to the mark in a $100 \mathrm{~cm}^{3}$ standard flask with $0.36 \mathrm{M}$ $\mathrm{HCl}$. Magnesium, calcium and zinc were determined using atomic absorption spectrophotometer (Buck scientific 210 VGP) while sodium and potassium were determined using flame photometer.

\section{Determination of antioxidant properties}

Determination of total phenol: The total phenol content of the composite flour was determined by the method of Singleton et al. ${ }^{30}$ About $0.2 \mathrm{ml}$ of the flour extract was mix with $2.5 \mathrm{ml}$ of $10 \%$ FolinCiocalteau's reagent and $2 \mathrm{ml}$ Sodium carbonate $(7.5 \%)$. The reaction mixture was subsequently incubated at $45^{\circ} \mathrm{C}$ for $40 \mathrm{~min}$, and the absorbance was measure at $700 \mathrm{~nm}$ in the spectrophotometer. The total phenolic compound in garlic acid equivalent (GAE) was calculated.

Determination of ferric reducing antioxidant power (FRAP) property: The reducing property of the composite flour was determined by the modified method of Oyaizu. ${ }^{31}$ Flour extract $(0.25 \mathrm{ml})$ was mixed with $0.25 \mathrm{ml}$ of $200 \mathrm{mM}$ of Sodium phosphate buffer $\mathrm{pH}$ 6.6 and $0.25 \mathrm{ml}$ of $1 \% \mathrm{KFC}$. The mixture was incubated at 50 for $20 \mathrm{~min}$, thereafter $0.25 \mathrm{ml}$ of $10 \%$ TCA was also added and centrifuge at $2000 \mathrm{rpm}$ for $10 \mathrm{~min}, 1 \mathrm{ml}$ of the supernatant was mixed with $1 \mathrm{ml}$ of distilled water and $0.1 \%$ of $\mathrm{Fecl}_{3}$ and the absorbance was measure at $700 \mathrm{~nm}$ and ferric reducing antioxidant property was calculated

Determination of DPPH free radical scavenging ability: The free radical scavenging ability of the extract against DPPH (1, 1- diphenyl2-picryhydrazyl) Using Singleton et al., ${ }^{30}$ method. The flour extract $(1 \mathrm{ml})$ was mixed with $1 \mathrm{ml}$ of the $0.4 \mathrm{mM}$ methanolic solution of the DPPH. The mixture was left in the dark for $30 \mathrm{~min}$ and the absorbance measured at $516 \mathrm{~nm}$.

Determination of oxalate: Oxalate determination was determine by soaking $1 \mathrm{~g}$ of the sample in $75 \mathrm{ml}$ of $1.5 \mathrm{~N} \mathrm{H}_{2} \mathrm{SO}_{4}$ for $1 \mathrm{hr}$ and then filter through a No 1 Whatman filter paper. The filtrate $(25 \mathrm{ml})$ will be placed inside a conical flask and titrated hot $\left(80-90^{\circ} \mathrm{C}\right)$ against $0.1 \mathrm{M}$ $\mathrm{KMnO}_{4}$ until a faint pink colour that persisted for $15 \mathrm{~s}{ }^{32}$ 
Statistical analysis: The data were analysed using SPSS version 16.0. The mean and standard error of means (SEM) of the triplicate analyses of the samples were calculated. The analysis of variance (ANOVA) was performed to determine significant differences between the means, while the means were separated using the Duncan New Multiple Range tests (DNMR).

\section{Results and discussion}

\section{Sensory evaluation of cookies}

The results of the sensory evaluation of the cookies are shown in Table 2. The overall acceptability ranged from 6.7 to 7.6. The analysis of variance showed that the sample with fermented millet (B4) had overall best acceptability, though not significant different $(\mathrm{p}<0.05)$ from sample with debranned millet (C5). In addition, sample B4 had the best colour, taste, appearance, and texture (Table 2).

\section{Proximate analyses}

The results of the proximate analyses are shown in Table 3 . The moisture content is generally low, as required for flours. There is no significance differences in all the values obtained for the various blends and for various processing (malting, fermenting and debranning). Altogether the values obtained are in range of the values obtained by Reihaneh and Jamuna.$^{33}$ Low moisture content is important in cookies production as it limit the water available for microbial activity and thereby resulting into a stable product with longer shelf life.

Table 2 Sensory evaluation of the biscuit produced from selected samples

\begin{tabular}{|c|c|c|c|c|c|c|}
\hline *Sample & Colour & Flavour & Taste & Appearance & Texture & Overall acceptability \\
\hline A4 & $6.3 \pm 1.0 \mathrm{I}^{\mathrm{a}}$ & $6 \pm 1.4^{\mathrm{a}}$ & $6.5 \pm 1.58^{a}$ & $6.1 \pm 0.88^{a}$ & $6.4 \pm\left. 1.7\right|^{\mathrm{a}}$ & $6.7 \pm 0.94^{\mathrm{a}}$ \\
\hline B4 & $7.5 \pm 0.85^{\mathrm{b}}$ & $6.21 \pm 1.5^{\mathrm{a}}$ & $7.1 \pm 1.6^{\mathrm{a}}$ & $7.4 \pm 1.08^{b}$ & $7.11 \pm 1.10^{c}$ & $7.6 \pm 1.10^{b}$ \\
\hline $\mathrm{C} 5$ & $6.3 \pm 0.48^{a}$ & $6.6 \pm 0.96^{a}$ & $7.3 \pm 1.16^{a}$ & $7.2 \pm 1.23^{b}$ & $6.6 \pm 0.5 \mathrm{I}^{\mathrm{b}}$ & $7.6 \pm 0.52^{b}$ \\
\hline
\end{tabular}

*A4 = 70:30:5:5:0.2 (rice: malted millet: soy: tigernut: CMC)

*B4 = 70:30:5:5:0.2 (rice: fermented millet: soy: tigernut: CMC)

*C5 = 60:40:5:5:0.2 (rice: debranned millet: soy: tigernut: CMC)

The ash content ranged from 1.62 to 1.78 for samples A; 1.62 to 1.63 for samples B and 1.63 to 1.65 for samples C. All the processes (malting, fermentation and debranning) reduce the ash contents significantly. Ash is indicative of the amount of minerals contained in any food sample.

The fat contents of the samples were above average. Fat, in addition to carbohydrate are sources of energy in food. Higher fat content is an indication of more total energies available. ${ }^{34}$ Addition of millet significantly increases the fat contents. Debranning had least reduction on fats, followed by malting and fermentation. Samples A5, B4 and C5 were significantly higher $(\mathrm{p}<0.05)$ in fat than other samples. In addition, the inclusion of soybean flour and tigernut flour to millet and rice flour may further increase the fat content. ${ }^{35,36}$

Protein content in the flour samples ranged from 10.08 to 14.78 . The high protein values of composite flour may be attributed to addition effect of soybean flour. Fermented millet flour had the highest protein value followed by malting. Debranning had pronounced reduction on the protein. It had been shown that fermentation process improves the nutritional value and reduces the risk of food borne illness, hence, beneficial health effects.

Carbohydrate contents are generally high. This will have good energy effects. Crude fibre reduces with malting, fermentation and debranning. Major health benefits associated with increased intake of dietary fibre includes reduce risk of heart diseases, diabetes, obesity and some forms of cancer (Table 3 ). ${ }^{37}$

\section{Functional properties of the composite flour}

The result of the functional properties is shown in (Tables 4A) (Tables 4B). Bulk density ranged from $(0.71 \mathrm{~g} / \mathrm{ml})$ to $(0.83 \mathrm{~g} / \mathrm{ml})$. Bulk density values decreased gradually with the flour blends containing malted and de-branned millet flour and increased slightly in the flour blends containing fermented millets with increase. The density of processed products dictate the characteristics of its container or package; product density influences the amount and strength of packaging material, texture or mouth feel. ${ }^{38}$ Values obtained from this study were comparable with the values reported by Okaka and Potter ${ }^{39}$ for cowpea $(0.60 \mathrm{~g} / \mathrm{ml})$ and also for pearl millet as reported by Singh et al. ${ }^{40}$ The decrease in bulk density of composite flour would be an advantage in the preparation of infant foods. Fermentation has been reported as a useful and traditional method for the preparation of low bulk weaning foods.

The swelling capacity of flours depends on size of particles, types of variety and types of processing methods or unit operations. As per literature, the flour of parboiled rice has more swelling capacity as compared to raw rice. The values of swelling capacity obtained in this study ranged from 21.28 to 30.7 at $50^{\circ} \mathrm{C}, 21.13$ to 33.3 at $60^{\circ} \mathrm{C}, 27.56$ to 45.5 at $75^{\circ} \mathrm{C}, 31.4$ to 39.9 at $90^{\circ} \mathrm{C}$. Malting (sample A30 had the highest swelling power.

The temperature at which gelatinization of starch takes place is known as the gelatinization temperature. ${ }^{31}$ The least gelation value obtained ranges from 1.2 to $2.2 \%$, the highest gelation value was observed for $\mathrm{C} 1$ which is the flour sample with the debranned millet flour and the lowest value obtained was in the categories of flour samples containing malted millet flour. The result falls within the range of the values obtained by Chandra and Samsher ${ }^{42}$ who reported the gelatinization of some flours such as wheat flour 1.94, rice flour 0.98 and potato flour 2.48. Due to higher starch content some flour gelatinize quickly while some will take more time due to lower starch content. 
Table 3 Proximate composition of the flour blends

\begin{tabular}{|c|c|c|c|c|c|c|}
\hline *Samples & $\begin{array}{l}\text { Moisture } \\
\text { (\%) }\end{array}$ & $\begin{array}{l}\text { Ash } \\
\text { (\%) }\end{array}$ & Crude fibre (\%) & $\begin{array}{l}\text { Crude protein } \\
\text { (\%) }\end{array}$ & Fat(\%) & Carbohydrate (\%) \\
\hline Al & $8.97 \pm 0.88$ & $1.78 \pm 0.03^{c}$ & $2.43 \pm 1.05^{\mathrm{d}}$ & $14.58 \pm 0.09^{f}$ & $4.9 \pm 0 . I^{\mathrm{ab}}$ & $69.89 \pm 1.52^{\mathrm{b}}$ \\
\hline $\mathrm{A} 2$ & $7.35 \pm 0.73$ & $1.78 \pm 0.02^{c}$ & $1.72 \pm 0.03^{\mathrm{abc}}$ & $13.47 \pm 0.00^{\mathrm{b}}$ & $5.40 \pm 0.07^{c}$ & $70.25 \pm 3.00^{\mathrm{b}}$ \\
\hline $\mathrm{A} 3$ & $7.62 \pm 0.67$ & $\mathrm{I} .64 \pm 0.0 \mathrm{I}^{\mathrm{ab}}$ & $1.8 \pm 0.15^{\mathrm{abc}}$ & $13.47 \pm 0.18^{b}$ & $5.8 \pm 0.05^{d}$ & $69.24 \pm 3.00^{\mathrm{b}}$ \\
\hline A4 & $6.93 \pm 0.39$ & $\mathrm{I} .65 \pm 0.0 \mathrm{I}^{\mathrm{b}}$ & $1.97 \pm 0.03^{\mathrm{cd}}$ & $13.82 \pm 0.00^{c}$ & $6.33 \pm 0.08^{f}$ & $69.59 \pm 1.53^{b}$ \\
\hline A5 & $8.23 \pm 0.15$ & $\mathrm{I} .62 \pm 0.0 \mathrm{I}^{\mathrm{a}}$ & $1.9 \pm 0.00^{\mathrm{bc}}$ & $14.08 \pm 0.27^{d}$ & $7.48 \pm 0.4 \mathrm{I}^{\mathrm{h}}$ & $66.86 \pm 153^{\mathrm{ab}}$ \\
\hline $\mathrm{BI}$ & $8.97 \pm 0.88$ & $1.78 \pm 0.03^{c}$ & $2.43 \pm 1.05^{d}$ & $14.58 \pm 0.09^{f}$ & $4.9 \pm 0 . I^{\mathrm{ab}}$ & $67.83 \pm 3.00^{\mathrm{ab}}$ \\
\hline B2 & $8.18 \pm 0.55$ & $1.63 \pm 0.02^{\mathrm{ab}}$ & $1.90 \pm 0.09^{\mathrm{bc}}$ & $14.28 \pm 0.10^{g}$ & $5.9 \pm 0.15^{\mathrm{de}}$ & $67.60 \pm 1.53^{\mathrm{ab}}$ \\
\hline B3 & $8.26 \pm 0.70$ & $1.63 \pm 0.02^{\mathrm{ab}}$ & $1.82 \pm 0.03^{\mathrm{abc}}$ & $14.78 \pm 0.1 \mathrm{I}^{\mathrm{h}}$ & $6.36 \pm 0.05^{f}$ & $66.62 \pm 3.00^{\mathrm{ab}}$ \\
\hline B4 & $7.22 \pm 0.15$ & $1.62 \pm 0.0 \mathrm{I}^{\mathrm{a}}$ & $1.74 \pm 0.09^{\mathrm{abc}}$ & $14.78 \pm 0.12^{\mathrm{h}}$ & $7.01 \pm 0.17^{g}$ & $69.78 \pm 3.00^{b}$ \\
\hline B5 & $8.95 \pm 2.57$ & $1.63 \pm 0.02^{\mathrm{ab}}$ & $1.62 \pm 0.03^{\mathrm{bc}}$ & $14.00 \pm 0.13^{i}$ & $6.22 \pm 0.13^{i}$ & $63.8 \pm 3.00^{\mathrm{a}}$ \\
\hline $\mathrm{Cl}$ & $8.97 \pm 0.88$ & $1.78 \pm 0.03^{c}$ & $2.43 \pm 1.05^{d}$ & $14.58 \pm 0.09^{f}$ & $4.63 \pm 0.12^{\mathrm{a}}$ & $70.86 \pm 3.00^{b}$ \\
\hline $\mathrm{C} 2$ & $8.23 \pm 0.10$ & $\mathrm{I} .65 \pm 0.0 \mathrm{I}^{\mathrm{ab}}$ & $1.33 \pm 0.03^{\mathrm{a}}$ & $10.08 \pm 0.14^{\mathrm{a}}$ & $5.00 \pm 0.13^{b}$ & $70.38 \pm 3.00^{b}$ \\
\hline C3 & $8.23 \pm 0.10$ & $1.64 \pm 0.02^{\mathrm{ab}}$ & $1.4 \pm 0.05^{\mathrm{ab}}$ & $10.73 \pm 0.16^{b c}$ & $6.1 \pm 0.21^{\text {ef }}$ & $70.17 \pm 1.53^{b}$ \\
\hline C4 & $8.23 \pm 0.10$ & $1.65 \pm 0.0 \mathrm{l}^{\mathrm{ab}}$ & $1.35 \pm 0.05^{\mathrm{ab}}$ & $11.75 \pm 0.17^{b c}$ & $6.78 \pm 0.0^{4 \mathrm{~g}}$ & $69.53 \pm 1.53^{b}$ \\
\hline C5 & $8.23 \pm 0.10$ & $\mathrm{I} .63 \pm 0.0 \mathrm{l} \mathrm{ab}$ & $1.35 \pm 0.05^{\mathrm{ab}}$ & $11.08 \pm 0.18^{\mathrm{d}}$ & $7.7 I \pm 0.33^{h}$ & $66.92^{\mathrm{ab}}$ \\
\hline
\end{tabular}


Table 4A Functional Properties of the composite flour blend

\begin{tabular}{|c|c|c|c|c|c|c|}
\hline \multirow[t]{2}{*}{ *Sample } & \multirow[t]{2}{*}{ Bulk density } & \multicolumn{4}{|c|}{ Swelling power } & \multirow[t]{2}{*}{ Least gelation } \\
\hline & & $50^{\circ} \mathrm{C}$ & $60^{\circ} \mathrm{C}$ & $75^{\circ} \mathrm{C}$ & $90^{\circ} \mathrm{C}$ & \\
\hline Al & $0.75 \pm 0.0 \mathrm{I}^{\mathrm{b}}$ & $22.4 \pm 0.00^{d}$ & $27.4 \pm 0.1^{c}$ & $43.7 \pm 0.00^{h}$ & $31.6 \pm 0.10^{a}$ & $1.2 \pm 0.00^{\mathrm{a}}$ \\
\hline $\mathrm{A} 2$ & $0.75 \pm 0.00^{\mathrm{b}}$ & $22.06 \pm 0.06^{c}$ & $29.7 \pm 0.10^{f}$ & $44.86 \pm 0.5^{i}$ & $31.56 \pm 0.06^{a}$ & $1.4 \pm 0.00^{\mathrm{ab}}$ \\
\hline A3 & $0.78 \pm 0.0 \mathrm{I}^{\mathrm{d}}$ & $20.36 \pm 0.06^{\mathrm{a}}$ & $23.03 \pm 2.50^{c}$ & $45.5 \pm 0.5^{j}$ & $32.66 \pm 0.15^{b}$ & $1.2 \pm 0.00^{\mathrm{a}}$ \\
\hline A4 & $0.82 \pm 0.0 \mathrm{I}^{\mathrm{f}}$ & $21.28 \pm 0.00^{b}$ & $26.36 \pm 0.15^{\mathrm{e}}$ & $36.32 \pm 0.0 I^{\mathrm{e}}$ & $35.5 \pm 0.10^{\mathrm{e}}$ & $1.4 \pm 0.00^{\mathrm{bc}}$ \\
\hline A5 & $0.78 \pm 0.0 \mathrm{I}^{\mathrm{d}}$ & $22.06 \pm 0.06^{c}$ & $27.46 \pm 0.45^{\mathrm{e}}$ & $41.26 \pm 0.06^{f}$ & $34.4 \pm 0.34^{d}$ & $1.2 \pm 0.00^{\mathrm{a}}$ \\
\hline BI & $0.83 \pm 0.0 \mathrm{I}^{\mathrm{f}}$ & $22.46 \pm 0.15^{d}$ & $30.4 \pm 0.10^{f}$ & $33.06 \pm 0.06^{d}$ & $31.4 \pm 0.00^{\mathrm{a}}$ & $1.6 \pm 0.00^{\mathrm{cd}}$ \\
\hline B2 & $0.8 \pm 0.0 \mathrm{I}^{\mathrm{e}}$ & $22.56 \pm 0.00^{d}$ & $30.13 \pm 0.12^{f}$ & $32.1 \pm 0.10^{c}$ & $36.16 \pm 0.15^{e}$ & $1.4 \pm 0.00^{\mathrm{bc}}$ \\
\hline B3 & $0.75 \pm 0.0 \mathrm{I}^{\mathrm{b}}$ & $30.6 \pm 0.10^{8}$ & $19.33 \pm 0.29^{a}$ & $36.4 \pm 0.10^{f}$ & $37.06 \pm 0.6^{h}$ & $1.6 \pm 0.00^{\mathrm{cd}}$ \\
\hline B4 & $0.7 I \pm 0.0 I^{a}$ & $22.81 \pm 0.15^{d}$ & $30.6 \pm 0.00^{f}$ & $36.32 \pm 0.0 \mathrm{I}^{\mathrm{f}}$ & $37.9 \mathrm{I} \pm 0.0 \mathrm{I}^{\mathrm{i}}$ & $1.4 \pm 0.00^{\mathrm{bc}}$ \\
\hline B5 & $0.79 \pm 0.00^{\mathrm{de}}$ & $30.7 \pm 0.00^{g}$ & $23.4 \pm 0.00^{\mathrm{cd}}$ & $36.6 \pm 0.0 \mathrm{I}^{f}$ & $36.7 \pm 0.2^{g}$ & $1.6 \pm 0.00^{\mathrm{cd}}$ \\
\hline $\mathrm{Cl}$ & $0.75 \pm 0.0 \mathrm{I}^{\mathrm{b}}$ & $24.66 \pm 0.0^{f}$ & $33.3 \pm 0.10^{g}$ & $29.6 \pm 0.52^{b}$ & $35.33 \pm 0.15^{e}$ & $2.2 \pm 0.00^{\text {ef }}$ \\
\hline $\mathrm{C} 2$ & $0.76 \pm 0.02^{c}$ & $23.86 \pm 0.06^{\mathrm{e}}$ & $24.36 \pm 0.15^{\mathrm{cd}}$ & $29.7 \pm 0.10^{\mathrm{b}}$ & $39.1 \pm 0.00^{k}$ & $1.6 \pm 0.00^{\mathrm{cd}}$ \\
\hline C3 & $0.78 \pm 0.0 \mathrm{I}^{\mathrm{d}}$ & $31.7 \pm 0.00^{\mathrm{h}}$ & $32.7 \pm 0.00^{g}$ & $27.56 \mathrm{v} 0.58^{\mathrm{a}}$ & $39.3 \pm 0.00^{k}$ & $2.00 \pm 0.00^{\text {de }}$ \\
\hline $\mathrm{C} 4$ & $0.75 \pm 0.0 \mathrm{I}^{\mathrm{b}}$ & $30.5 \pm 0.5^{g}$ & $21.13 \pm 0.12^{b}$ & $34.73 \pm 0.21^{\mathrm{e}}$ & $33.63 \pm 0.15^{c}$ & $2 \pm 0.00^{\mathrm{de}}$ \\
\hline C5 & $0.75 \pm 0.00^{b}$ & $22 \pm 0.00^{c}$ & $21.85 \pm 0.01^{b}$ & $34.4 \pm 0.10^{e}$ & $37.66 \pm 0.0 I^{i}$ & $1.8 \pm 0.00^{\mathrm{ds}}$ \\
\hline
\end{tabular}

*AI, $\mathrm{BI}, \mathrm{CI}=100: 0: 5: 5: 0.2$ (rice: millet: soy: tigernut: $\mathrm{CMC}$ )

*A2, B2, C2 = 90: 10:5:5:0.2 (rice: millet: soy: tigernut: CMC)

*A3, B3, C3 = 80:20:5:5:0.2 (rice: millet: soy: tigernut: CMC)

*A4, B4, C4 = 70:30:5:5:0.2 (rice: millet: soy: tigernut: CMC)

*A5, B5, C5 = 60:40:5:5:0.2 (rice: millet: soy: tigernut: CMC)

Table 4B Functional properties of composite flour (Continued)

\begin{tabular}{llll}
\hline *Sample & OAC & WAC & Dispensability \\
\hline AI & $1.70 \pm 0.01^{\mathrm{a}}$ & $2.16 \pm 0.05^{\mathrm{c}}$ & $60 \pm 0.00^{\mathrm{a}}$ \\
A2 & $1.9 \pm 0.00^{\mathrm{c}}$ & $2.20 \pm 0.00^{\mathrm{b}}$ & $68 \pm 0.00^{\mathrm{d}}$ \\
A3 & $1.8 \pm 0.00^{\mathrm{b}}$ & $2.16 \pm 0.05^{\mathrm{b}}$ & $66 \pm 1.0^{\mathrm{d}}$ \\
A4 & $1.81 \pm 0.01^{\mathrm{b}}$ & $2.06 \pm 0.05^{\mathrm{ab}}$ & $70 \pm 0.00^{\mathrm{ef}}$ \\
A5 & $1.8 \pm 0.10^{\mathrm{d}}$ & $2.03 \pm 0.05^{\mathrm{ab}}$ & $72 \pm 1.0^{\mathrm{hi}}$ \\
BI & $1.70 \pm 0.01^{\mathrm{a}}$ & $2.16 \pm 0.05^{\mathrm{c}}$ & $60 \pm 0.00^{\mathrm{a}}$ \\
B2 & $1.80 \pm 0.10^{\mathrm{b}}$ & $2.06 \pm 0.05^{\mathrm{ab}}$ & $65 \pm 0.00^{\mathrm{cd}}$ \\
B3 & $1.90 \pm 0.01^{\mathrm{c}}$ & $2.23 \pm 0.03^{\mathrm{b}}$ & $70.66 \pm 0.58^{\mathrm{d}}$ \\
B4 & $2.1 \pm 0.00^{\mathrm{e}}$ & $2.13 \pm 0.05^{\mathrm{b}}$ & $72.5 \pm 1.53^{\mathrm{i}}$ \\
B5 & $1.8 \pm 0.00^{\mathrm{b}}$ & $2.1 \pm 0.00^{\mathrm{ab}}$ & $66.33 \pm 1.53^{\mathrm{d}}$ \\
\hline
\end{tabular}

Citation: Awolu OO, Olarewaju OA, Akinade A. Effect of the addition of pearl millet flour subjected to different processing on the antioxidants, nutritional, pasting characteristics and cookies quality of rice-based composite flour.J Nutr Health Food Eng. 20I7;7(2):247-256. DOI: I0.15406/jnhfe.20I7.07.00232 
Table continued..

\begin{tabular}{llll} 
*Sample OAC & WAC & Dispensability \\
\hline $\mathrm{Cl}$ & $1.70 \pm 0.01^{\mathrm{a}}$ & $2.16 \pm 0.05^{\mathrm{c}}$ & $60 \pm 0.00^{\mathrm{a}}$ \\
$\mathrm{C} 2$ & $2.13 \pm 0.12^{\mathrm{e}}$ & $1.53 \pm 1.15^{\mathrm{a}}$ & $64 \pm 1.00^{\mathrm{c}}$ \\
$\mathrm{C} 3$ & $2 \pm 0.00^{\mathrm{e}}$ & $1.86 \pm 0.06^{\mathrm{ab}}$ & $68 \pm 0.00^{\mathrm{e}}$ \\
$\mathrm{C} 4$ & $1.8 \pm 0.1^{\mathrm{b}}$ & $2.16 \pm 0.06^{\mathrm{a}}$ & $61.66 \pm 1.53^{\mathrm{b}}$ \\
$\mathrm{C} 5$ & $2.1 \pm 0.00^{\mathrm{e}}$ & $2.00 \pm 0.00^{\mathrm{ab}}$ & $65.5 \pm 0.7 \mathrm{I}^{\mathrm{d}}$
\end{tabular}

*AI, $\mathrm{BI}, \mathrm{CI}=100: 0: 5: 5: 0.2$ (rice: millet: soy: tigernut: CMC)

$* A 2, B 2, C 2=90: 10: 5: 5: 0.2$ (rice: millet: soy: tigernut: CMC)

$* A 3, B 3, C 3=80: 20: 5: 5: 0.2$ (rice: millet: soy: tigernut: $C M C$ )

*A4, B4, C4 = 70:30:5:5:0.2 (rice: millet: soy: tigernut: CMC)

$* A 5, B 5, C 5=60: 40: 5: 5: 0.2$ (rice: millet: soy: tigernut: $C M C$ )

Oil absorption capacity was highest in composite flour comprising debranned millet, followed by the blends with fermented millet. $\mathrm{OAC}$ increases as degree of substitution of millet blends increases. Overall, oil absorption capacity values ranged from 1.70 to 2 . The oil-absorption capacity of these flour blends suggests that it is not useful for baking alone but would also be useful in formulation of foods where oil absorption property is an important consideration. Most cereals contained good oil absorption capacity as reported for sorghum $(7.03 \mathrm{ml} / \mathrm{g})$, pearl millet $(6.7 \mathrm{ml} / \mathrm{g})$ and maize $(6.9 \mathrm{~m} / \mathrm{g})$ by Singh et al..$^{40}$ These results are in agreement with Elkhalifa et al., ${ }^{43}$ who reported about $7 \%$ increase in oil absorption capacity after $8 \mathrm{~h}$ of fermentation of sorghum flour. Awolu et al., ${ }^{3}$ reported OAC ranging from 1.75 to 2.21 for rice, cassava and kersting's groundnut composite flour. Variation in oil absorption capacity might be due to the different proportion of the protein molecules present in each of the samples.

The water absorption capacity ranged from 1.53 to 2.23 . WAC is highest in blends with fermented millet followed by blend with malted millet. There are significant differences between the blends. The result obtained is similar to that obtained by Awolu et al., ${ }^{3}$ for rice, cassava and kersting's groundnut composite flour. The ability of flour to absorb water was reported to have a significant correlation with its starch content. ${ }^{44}$ High WAC assures product cohesiveness due to loose association of amylose in starch granules and weakness associative force ${ }^{45}$ Water absorption capacity gives an indication of the amount of water available for gelatinization. Lower absorption capacity is desirable for making thinner gruels.

The dispersibility of the flour blends ranged from 60 to $70 \%$. Malted and fermented millet flour blends had the highest dispersibility while debranned millet flour blends the least. Malomo Olu et al., ${ }^{46}$ discovered that $100 \%$ yam flour had higher dispersibility than yam flour enriched with soy; $100 \%$ yam flour had higher WAC. Higher dispersibility indicated flour that is easily reconstituted. ${ }^{46}$ The high values of dispersibility showed that the blends will be easily reconstituted to give fine consistency dough during mixing (Table 4A) (Table 4B). ${ }^{47}$

\section{Best blends}

The three best blends chosen; one for each of malted, fermented and debranned millet, based on the results of the proximate and functional analyses were samples A4, B4 and C5.

\section{Pasting characteristics}

The results of the pasting properties are shown in Table 5. The peak viscosity ranged from 133 to 184 RVU. Peak viscosity indicates the maximum swelling capacity of starch granules. ${ }^{48}$ It also indicates the water binding capacity of the starch granules. Flour blend with fermented millet (B4) had the highest peak viscosity, followed by blend with malted millet (A4). The trough was highest in fermented millet blend, followed by debranned millet blend.

Breakdown viscosity was highest in blend with malted millet, followed by blend with fermented millet. Breakdown measures the ease with which the swollen granules can disintegrate..$^{49}$ It has been explained that the higher the breakdown, the lower the ability of the starch to withstand heating and shear stress during cooking, ${ }^{50}$ hence, blend with debranned millet had highest stability.

The final viscosity is the ability of the starch to form a viscous paste. ${ }^{51}$ A reduced final viscosity indicated a reduced ability of sample to form viscous paste. All the samples showed reduction in final viscosity. A4 showed 34\% reduction, B4 showed $7.4 \%$ reduction while $\mathrm{C} 5$ showed $1.8 \%$ reduction.

Set back as be described as a measure of recrystallization of gelatinized starch after cooling. ${ }^{51}$ It has been shown that high amylose content resulted in increased tendencies of syneresis and retrogradation ${ }^{52}$ Chang and Liu. Sample B4 had the highest setback, followed by $\mathrm{A} 4$ and then $\mathrm{C} 5$.

The pasting temperature ranged from 91.45 to 92.45 . Sample C5 had the highest pasting temperature, followed by A4 and then B4. Pasting temperature is an indication of the minimum temperature required to cook the flour. ${ }^{49}$ Overall, sample B4 showed highest dough swelling capacity while sample C5 showed highest dough stability

\section{Mineral analysis}

The mineral contents of the selected flour blends are shown in Table 6. Sample B4 had the highest value of potassium, zinc and sodium, sample A4 was high in calcium and magnesium. Although minerals are micronutrients, and are required in a minute amount in the body, they are needed for specific immune functions and their absence can result in certain deficiency diseases.

\section{Antioxidant and antinutrition properties of samples}

The results of antioxidant and antinutrition properties are presented in Table 7. The DPPH values obtained for the samples were high as a result of the presence of pearl millet in the flour samples. Pearl millet had been shown to possess high antioxidant properties. ${ }^{11}$ Antioxidants are reducing agents ${ }^{53}$ and counter the accumulation of free radicals in the body. Oboh \& Rocha ${ }^{54}$ had demonstrated reducing power of flour samples.

Phenols and phenolic compounds have been reported to possess significant antioxidant activities. ${ }^{55}$ The total phenolic content of the sample containing fermented millets (B4) is higher than what was reported by Oboh et al., ${ }^{56}$ for fermented African locust bean. This indicates that regular consumption of fermented pearl millet may serve as a dietary source of antioxidants. Also, the values obtained were higher than what was obtained for Carica papaya and Cajanus cajan by Imaga et al. ${ }^{57}$ These higher values agree with report of Vattem et al., ${ }^{58}$ that fermentation of cranberry pomace improved phenolic content and antioxidant activity. 
Table 5 Pasting properties of the composite flour samples

\begin{tabular}{llllllll}
\hline *Sample & Peak & Trough & Breakdown & Final visc & Setback & Peak time & Pasting temp $\left({ }^{\circ} \mathbf{C}\right)$ \\
\hline & $\mathbf{( R V U )}$ & $\mathbf{( R V U )}$ & $\mathbf{( R V U )}$ & $\mathbf{( R V U )}$ & $\mathbf{( R V U )}$ & & \\
\hline A4 & 184.08 & 83.67 & 100.42 & 121.58 & 37.92 & 6.33 & 92.35 \\
B4 & 206.75 & 128.58 & 78.17 & 191.25 & 62.67 & 5.75 & 91.45 \\
C5 & 133.17 & 94.83 & 38.33 & 130.83 & 36 & 6.95 & 92.42 \\
\hline
\end{tabular}

*A4 = 70:30:5:5:0.2 (rice: malted millet: soy: tigernut: CMC)

*B4 = 70:30:5:5:0.2 (rice: fermented millet: soy: tigernut: CMC)

$*$ C5 $=$ 60:40:5:5:0.2 (rice: debranned millet: soy: tigernut: CMC)

Table 6 Minerals content of selected samples (ppm)

\begin{tabular}{llllll}
\hline Sample & $\mathbf{M g}$ & $\mathrm{Ca}$ & $\mathbf{K}$ & $\mathrm{Na}$ & $\mathbf{Z n}$ \\
\hline A4 & $1.17 \pm 0.3^{\mathrm{c}}$ & $2.4 \pm 0.10^{\mathrm{c}}$ & $42.21 \pm 1.43^{\mathrm{a}}$ & $13.6 \pm 0 . \mathrm{I}^{\mathrm{b}}$ & $0.45 \pm 0.0 \mathrm{I}^{\mathrm{b}}$ \\
B4 & $0.8 \pm 0.10^{\mathrm{b}}$ & $2.1 \pm 0.10^{\mathrm{b}}$ & $83.45 \pm 0.05^{\mathrm{c}}$ & $16.7 \pm 0.2^{\mathrm{c}}$ & $0.56 \pm 0.0 \mathrm{I}^{\mathrm{c}}$ \\
C5 & $0.7 \pm 0.10^{\mathrm{a}}$ & $\mathrm{I} .7 \pm 0.10^{\mathrm{a}}$ & $55.3 \pm 0.8^{\mathrm{b}}$ & $12.20 \pm 0.0 \mathrm{I}^{\mathrm{a}}$ & $0.4 \mathrm{I} \pm 0.0 \mathrm{I}^{\mathrm{a}}$ \\
\hline
\end{tabular}

Table 7 Antioxidant and anti nutrition properties of some selected samples

\begin{tabular}{lllll}
\hline Sample & Antioxidants & & & Anti nutrition \\
\hline & Frap & Phenol & DPPH & Oxalate \\
\hline A4 & $3.24 \pm 0.19^{\mathrm{b}}$ & $0.98 \pm 0.03^{\mathrm{b}}$ & $60.45 \pm 0.93^{\mathrm{c}}$ & $0.27 \pm 0.0^{\mathrm{a}}$ \\
B4 & $3.69 \pm 0.1 \mathrm{I}^{\mathrm{c}}$ & $2.47 \pm 0.39^{\mathrm{c}}$ & $52.23 \pm 0.22^{\mathrm{b}}$ & $0.58 \pm 0.06^{\mathrm{b}}$ \\
C5 & $2.41 \pm 0.2 \mathrm{I}^{\mathrm{a}}$ & $0.92 \pm 0.34^{\mathrm{a}}$ & $10.86 \pm .0 .14^{\mathrm{a}}$ & $0.8 \mathrm{I} \pm 0.00^{\mathrm{c}}$
\end{tabular}

FRAP assay measures the reducing potential of an antioxidant reacting with a ferric tripyridyltriazine ( $\mathrm{Fe}^{3+}$-TPTZ) complex and producing coloured ferrous tripyridyltriazine ( $\left.\mathrm{Fe}^{2+}-\mathrm{TPTZ}\right){ }^{59}$ Generally, the reducing properties are associated with the presence of compounds which exert their action by breaking the free radical chain by donating a hydrogen atom. ${ }^{60}$ According to Benzie and Strain, ${ }^{59}$ the reduction of $\mathrm{Fe}^{3+}$-TPTZ complex to blue-coloured $\mathrm{Fe}^{2+}$-TPTZ occurs at low $\mathrm{pH}$. FRAP values of sample B4 were significantly higher than other samples which A4 and C5.

Oxalates limit the availability of calcium in the body, being calcium binders. The results of the antinutritional evaluation of the selected flour samples showed that it ranged from 0.27 to 0.81 . The oxalate level of sample A4 was the lowest which indicated that the malting had ability to reduce oxalate. It had been found that soaking reduces oxalate contents of samples Njoki. The oxalate levels in samples B4 and $\mathrm{C} 5$ are safe for human consumption.

\section{Conclusion}

The effect of addition of pearl millet subjected to different processing techniques on the composite flour comprising rice, soybeans and tigernut on the proximate composition, functional and pasting properties evaluated showed that the addition of fermented pearl millet flour was the best compared to debranned and malted pearl millet flours; fermentation increases the protein contents of the composite flours; malting, fermentation and debranning increases the functional properties. In general the all the composite flours had good and acceptable nutritional and flour quality which could be used in producing acceptable cookies.

\section{Acknowledgements}

None.

\section{Conflict of interest}

Authors declare that there is no conflict of interest.

\section{References}

1. Jayathilakan K, Sultana K, Harilal PT, et al. Effect of ground chicken incorporation on the nutritional, textural and sensory characteristics of shelf stable biscuits. International Journal of Advanced Research. 2015;3(6):751-761.

2. Tyagi SK, Manikantan MR, Oberoi HS. Effect of mustard flour incorporation on nutritional, textural and organoleptic characteristics of biscuit. Journal of Food Engineering. 2006;80(4):1043-1050.

3. Awolu OO, Oluwaferanmi PM, Fafowora OI, et al. Optimization of the extrusion process for the production of ready-toeat snack from rice, cassava and kersting's groundnut composite flours. LWT Food Science and Technology. 2015;64(1):18-24.

4. Omoba OS, Awolu OO, Olagunju AI, et al. Optimisation of Plantainbrewers' spent grain biscuit using response surface methodology. Journal of Scientific Research \& Reports. 2013;2(2):665-681.

5. Awolu OO. Optimization of the functional characteristics, pasting and rheological properties of pearl millet-based composite flour. Heliyon. 2017;3(2).

6. Awolu OO, Omoba OS, Olawoye O, et al. Optimization of production and quality evaluation of maize-based snack supplemented with soybean and tiger-nut (Cyperus esculenta) flour. Food Sci Nutr. 2017;5(1):3-13. 
7. Awolu OO, Osemeke RO, Ifesan BOT. Antioxidant, functional and rheological properties of optimized composite flour, consisting wheat and amaranth seed, brewers' spent grain and apple pomace. J Food Sci Technol. 2016;53(2):1151-1163.

8. Agu HO, Ayo JA, Paul AM, et al. Quality characteristics of biscuits made from wheat and African breadfruit (Treculia africana). Nigerian food Journal. 2007;25(2):19-27.

9. Olaoye OA, Onilude AA, Oladoye CO. Breadfruit flour in biscuit making: effects on product Quality. African Journal of Food Science. 2007:20-23.

10. Ojediran JO, Adamu MA, Jim-George DL. Some physical properties of Pearl millet (Pennisetum glaucum) seeds as a function of moisture content. African Journal of General Agriculture. 2010;6(1):29-46.

11. Odusola, KB, Ilesanmi FF, Akinloye OA. Assessment of nutritional composition and antioxidant ability of pearl millet (Pennisetum glaucum). American Journal of Research Communication. 2013;1(6):262-272.

12. Helms S. Celiac disease and gluten-associated diseases. Altern Med Rev. 2005;10(3):172-192.

13. Alabi MO, Anukonye JC. Nutritional and sensory attributes of soy supplemented cereal meals. Nigeria Food Journal. 2007;25(1):100-110.

14. Kure OA, Bahago EJ, Daniel EA. Studies on the proximate composition and effect of flour particle size of acceptability of biscuits produced from blends of soybeans and plantain flours. Journal of Namoda Technology. 1998;3(2):17-22

15. Basman A, Koksel H. Utilization of transgluranase use to increase the level of barley and soy flour incorporation in wheat flour breads. J Food Sci. 2003;68(8):2453-2460.

16. Olaoye OA, Onilude AA, Idowu OA. Quality characteristics of bread produced from composite flours of wheat, plantain and soybeans. African Journal of Biotechnology. 2006;5(11):1102-1106.

17. Anderson JW, Smith BM, Gustafson NJ. Health benefits and practical aspects of high fiber diets. Am J Clin Nutr. 1994;59(5 suppl):1242S-1247S

18. Oladele AK, Aina JO. Chemical composition and functional properties of flour from two varieties of tigernut (Cyperus esculentus). African Journal of Biotechnolology. 2007;6(21):2473-2476.

19. Lei V, Jakobsen M. Microbiological characterization and probiotic potential of koko and koko sour water, African spontaneously fermented millet porridge and drink. J Appl Microbiol. 2004;96(2):384-397.

20. Pelembe LAM, Dewar J, Taylor JRN. Effect of malting conditions on pearl millet quality. Journal of the Institute of Brewing. 2012;108(1):7-12.

21. Adeyemi IA. Ogi quality sorghum dry milled from fermented Sorghum Grains. Journal of Food Science. 1988;53(2):641-642.

22. Ihekoronye A. Manual of mall scale food processing. 1st ed. Nigeria: Academic Publishers Nsukka; 1999. 32p.

23. Official methods of analysis of AOAC. Association of official Analytical chemist. 17th ed. Washington DC, USA; 2000.

24. Fagbemi TN, Adeoya AS, Badejo AA. Effect of Sulphiting on the Physical and Functional Properties of Acetylated Cassava (Manihot esculenta) Starch. Food. 2012;6(1):38-43.

25. Sathe SK, Desphande SS, Salunkhe DK. Functional properties of Lupin seed (Lupinus mutabilis) proteins and protein concentrates. Journal of Food Science. 1982;47:491-497.

26. Coffman CW, Garcia VV. Functional properties and amino acid content of protein isolate from mung bean flour. Journal of Food Technology. 1977;12(5):473-484.
27. Takashi S, Seib PA. Paste and gel properties of prime corn and wheat starches with and without native lipids. Cereal Chem. 1988;65(6):474-483.

28. Kulkarni KD, Kulkarni DN, Ingle UM. Sorghum malt based winning formulations, preparations, functional properties and nutritive values. Food and Nutrition Bulletin. 1991;13:322-329.

29. Sanni AI, Sefa-Dedeh S, Sakyi-Dawson E, et al. Microbiological evaluation of Ghanaian maize dough co- fermented with cowpea. Int J Food Sci Nutr. 2004;53(5):367-373

30. Singleton VL, Orthofer R, Lamuela-Raventós RM . [14] Analysis of total phenols and other oxidation substrates and antioxidants by means of folin-ciocalteu reagent. Methods in enzymology. 1999;299:152-178.

31. Oyaizu M. Studies on products of browning reaction-antioxidative activities of products of browning reaction prepared from glucosamine. Japanese Journal of Nutrition. 1986;44(6):307-315.

32. Day RA, Underwood AL. Quantitative analysis. 5th ed. USA: PrenticeHall publication, Upper Saddle River; 1986. 701p.

33. Reihaneh AG, Jamuna P. The impact of germination and dehulling on nutrients, antinutrients, in vitro iron and calcium bioavailability and in vitro starch and protein digestibility of some legume seeds. LWT Food Science and Technology. 2006;40(7):1292-1299.

34. Belewu MA, Belewu KY. Comparative physico- evaluation of tiger-nut, soybean and coconut milk sources. International Journal of agricultural and biological engineering. 2007;9:785-787.

35. Oti E, Akobundu ENT. Potentials of cocoyam-soyabean-crayfish mixtures in complementary feeding. Nigeria Agricultural Journal. 2008;39(2):137-145.

36. Emovon E. Keynote address P.O.C of training workshop on utilization of soybean. ABU Zaria, Nigerian Home Economics Series No. 1987;4:6-10.

37. Marlett JA, McBurney MI, Slavin JL. Position of the American dietetic association: Health implications of dietary fiber. Journal of the American Dietetic Association. 2002;102(7):993-1000.

38. Wilhelm LR, Dwayna AS, Gerand HB. Introduction to problem solving skills. In: Food and Process Engineering Technology. ASAE. 2004.

39. Okaka NC, Potter N. Physico-chemical and Functional Properties of cowpea powder processed to reduce beany flavour. Journal of Food Science. 1979;44(4):1235-1240.

40. Singh A, Yadav N, Sharma S. Effect of fermentation on physicochemical properties and in vitro starch and protein digestibility of selected cereals. International Journal of Agriculture and Food Science. 2012;2(3):66-70.

41. Sahay KM, Singh KK. Unit operations of Agricultural Processing. New Delhi: Vikas Publishing; 1996. 237p.

42. Chandra S, Samsher. Assessment of functional properties of different flours. African Journal of Agricultural Research . 2013;8(38):4849-4852.

43. Elkhalifa AEO, Schiffler B, Bernhard R. Effect of fermentation on the functional properties of sorghum flour. Food Chemistry. 2005;92(1):1-5.

44. Mbofung CMF, Abuobakar YN, Njintang A, et al. Physico-chemical and functional properties of six varietes of Taro (Colocasia esculenta $L$. schott) flour. Journal of Food Technology. 2006;4(2):135-142.

45. Houson P, GS Ayenor. Appropriate processing and food functional properties of maize flour. African Journal of Science and Technology. 2002;3(1):126-131

46. Malomo Olu, Ogunmoyela OAB, Adekoyeni OO, et al. Rheological and Functional Properties of Soy-Poundo Yam Flour. International Journal of Food Science and Nutrition Engineering. 2012;2(6):101-107. 
47. Adebowale AA, Sanni LO, Fadaunsi EL. Functional Properties of Cassava-Sweet Potato Starch Blend. Proceeding of the 32nd Annual Conference of Nigerian Institute of Food Science and Technology. 2008. p. 304-305.

48. Ho LH, Noor Aziah AA. Dough mixing and thermal properties including the pasting profiles of composite flour blends with added hydrocolloids. International Food Research Journal. 2013;20(2):911-917.

49. Kaur M, Singh N. Studies on functional thermal and pasting properties of flours from different chickpea (Cicer arietinum L.) cultivars. Food Chemistry. 2005;91(3):403-411.

50. Adebowale AA, Sanni LO, Awonorin SO. Effect of texture modifies on the physiochemical and sensory properties of dried fufu. Journal of Food Science and Technology International. 2005;11:373-385.

51. Ashogbon AO, Akintayo ET. Morphological, functional and pasting properties of starches separated from rice cultivars grown in Nigeria. International Food Research Journal. 2012;19(2):665-671.

52. Adebowale KO, Lawal OS. Microstructure, functional properties and retrogradation behavior of muxcuna beans (Mucuna pruriens) starch on heat moisture treatments. Food Hydrocolloids. 2003;17:265-272.

53. Sies H. Strategies of antioxidant defense. Eur $J$ Biochem. 1993;215(2):213-219.

54. Oboh G, Rocha JBT. Polyphenols in red pepper [capsicum annum var. aviculare (Tepin)] and their protective effect on some pro-oxidants induced lipid peroxidation in brain and liver. European food Research and Technology. 2007;225(2):239-247.
55. Aiyegoro OA, Okoh AI. Phytochemical Screening and Polyphenolic Antioxidant Activity of Aqueous Crude Leaf Extract of Helichrysum pedunculatum. Int J Mol Sci. 2009;10(11):4990-5001.

56. Oboh G, Alabi KB, Akindahunsi AA. Fermentation changes the nutrition value, polyphenols distribution and antioxidant properties of parkia biglobosa seeds. Food Biotechnology. 2008;22(4):363-376.

57. Imaga NOA, Gbenle GO, Okochi VI, et al. Antisickling property of Carica papaya leaf extract. African Journal of Biochemistry Research. 2009;3(4):102-106.

58. Vattem D, Lin YT, Labba R, et al. Phenolic antioxidant mobilization in cranberry pomace by solid state bio-processing using food grade fungus lentisedodes and effect on antimicrobial activity against selected food borne pathogens. Innovative Food Science and Emerging Technologies. 2004;5(1):81-91.

59. Benzie IFF, Strain JJ. The ferric reducing ability of plasma as a measure of "antioxidant power" the FRAP assay. Anal Biochem. 1996;239(1):70-76.

60. Kubol J, Siriamornpun S. Phenolic contents and antioxidant activities of bitter gourd (Momordica charantia L.) leaf, stem and fruit fraction extracts in vitro. Food Chemistry. 2008;110(4):881-890. 